Maruí Weber Corseuil Giehl'

Ione Jayce Ceola Schneider'

Herton Xavier Corseuil"

Tânia Rosane Bertoldo

Benedetti"

Eleonora d'Orsi'

\section{Physical activity and} environment perception among older adults: a population study in Florianópolis, Brazil

\begin{abstract}
OBJECTIVE: To estimate the prevalence of the practice of leisure-time physical activity in older adults and to analyze its association with environment perception.

METHODS: Cross-sectional population study conducted from September 2009 to June 2010 with 1.656 individuals aged 60 years or older, living in the urban zone of the city of Florianópolis, Southern Brazil. Leisure-time physical activity was measured using the long version of the International Physical Activity Questionnaire. Environment perception variables were measured by means of a modified version of the Neighborhood Environment Walkability Scale. Crude and adjusted analyzes were carried out using Poisson regression with a $5 \%$ significance level.
\end{abstract}

RESULTS: The prevalence of leisure-time physical activity was $29.7 \%(95 \%$ CI: 26.0 ; 33.3); 35.6\% (95\%CI: 29.7 ; 41.6) among men and $26.3 \%(95 \%$ CI: $23.1 ; 29.4)$ among women. The elderly who reported the existence of sidewalks, bike lanes, pedestrian paths and trails in the neighborhood, as well as those who reported receiving support from friends or neighbors to engage in physical activities, were more active in their leisure time. Concerning the influence of the climate, the elderly who reported that it was a barrier were rated as more active.

CONCLUSIONS: The practice of leisure-time physical activity still has low prevalence among the elderly population of Florianópolis. Public spaces for the practice of physical activity and encouraging group activities may play a significant role in the promotion of leisure-time physical activity in older adults.

DESCRIPTORS: Aged. Motor activity. Leisure Activities. Perception Environment. Social Environment. Cross-sectional studies.

\section{INTRODUCTION}

Regular physical activity can reduce the risk factors associated with morbidity and mortality among older adults. Being physically active can alter the course of many diseases that are prevalent in this population. . $^{12,18,22}$

It is known that the practice of physical activity decreases as age advances. Thus, a large part of the elderly population is physically inactive, mainly in leisure time. ${ }^{1,13,25}$ This population group has more available time due to retirement; therefore, the evaluation of the activities in this domain is an important indicator of their level of physical activity. ${ }^{25}$

This theme has been approached mainly in investigations of the association between levels of physical activity and sociodemographic ${ }^{13,25}$ and health ${ }^{22}$ factors, leaving a gap in the understanding of the variables related to the 
environmental factors that best explain this behavior in the elderly population.

Recent international studies ${ }^{7,11,15}$ have shown constant associations between active behavior and environments that facilitate the practice of physical activity. However, only one study was found in Brazil about the theme with the elderly population. ${ }^{21}$

Thus, the aim of the present study was to estimate the prevalence of leisure-time physical activity in older adults and to analyze its association with environment perception.

\section{METHODS}

This is a cross-sectional, population, household-based study conducted from September 2009 to June 2010, with a sample composed of elderly individuals aged 60 or older living in the urban zone of the city of Florianópolis, Southern Brazil. The study is part of a comprehensive inquiry ${ }^{\mathrm{a}}$ into the health conditions of the elderly people of Florianópolis, carried out in 2009/2010, and called EpiFloripa Idoso.

The municipality of Florianópolis, the capital city of the State of Santa Catarina, had in $2009^{\mathrm{b}}$ an estimated population of 408, 163 inhabitants. Of this total, 44,460 belonged to the group with age equal to or above 60 years $(10.8 \%$ of the overall population). The city presented a municipal human development index of 0.88 in 2000 , which placed it in the fourth position among the Brazilian municipalities, and life expectancy at birth was 72.8 years. $^{\mathrm{c}}$

Sample size estimation considered population's size of 44,460 , estimate of prevalence of leisure-time physical activity of $26 \%,{ }^{6}$ sampling error of 4 percentage points, a $95 \%$ confidence interval, design effect of 2.6 , addition of $20 \%$ for possible losses and refusals and $15 \%$ to control for confounding factors in association studies. Therefore, a sample of 1,604 individuals was necessary. The total sample of EpiFloripa Idoso was used, calculated in 1,599 individuals. The calculations were made in the program EpiInfo, version 6.04.

Two-stage cluster sampling was carried out. In the first stage, the 420 urban census tracts were stratified according to income deciles of the head of household. Eight sectors were drawn in each decile (a total of 80 sectors). The sampling units of the second stage were the households, which were drawn in a systematic way. It was necessary to have a stage to update the number of households inhabited in each sector, as the most recent Census had been performed in 2000. The number of inhabited households varied from 61 to 725 . To reduce the coefficient of variation among the number of households of the sampling units, the sectors were merged and divided, respecting the correspondent income decile. Thus, the initial coefficient of variation was reduced from $52.7 \%(\mathrm{n}=80$ sectors $)$ to $35.2 \%(\mathrm{n}=83$ sectors $)$. It was estimated that 60 households should be visited per sector, in order to find 20 elderly individuals. All the elderly living in the drawn households were considered eligible for the study.

Institutionalized elderly individuals were excluded. Interviews that were not performed after four attempts (including the evening period and weekends) were considered losses, and subjects who did not answer the questionnaire as a personal option were considered refusals. No substitutions were made.

Data was collected by trained interviewers who had completed Secondary Education and were fully available to perform the fieldwork. A structured questionnaire with pre-coded questions was administered in the form of face-to-face interviews. Personal digital assistants were used, which eliminated the manual keyboarding of the data. Before the data collection, a pre-test with 30 elderly people and a pilot study with approximately 100 elderly people were carried out, in sectors that were not sampled to the research.

Data consistency was verified on a weekly basis and incomplete or inconsistent information was corrected in a second interview whenever necessary. Quality control was performed once a week by means of the administration of a reduced questionnaire, by telephone, to $10 \%$ of the interviews (which were randomly selected).

The outcome variable of the present study was level of leisure-time physical activity, measured by the long version of the International Physical Activity Questionnaire (IPAQ), adapted and validated to older adults of Brazil. ${ }^{5}$ Individuals who practiced 150 minutes per week or more of leisure-time physical activity were classified as physically active in this domain. ${ }^{18}$

The exploratory variable was environment perception, collected by means of an adapted version ${ }^{21}$ of the Neighborhood Environmental Walkability Scale (NEWS), validated to Brazil. ${ }^{16}$ The alternatives of answers of the adapted version of the NEWS scale were standardized as dichotomic (yes or no). Environment perception was composed of 22 questions related to the individual's perception of the physical and environmental structures close to his/her home, like the presence and quality of the sidewalks; presence of

\footnotetext{
a Research "Condições de saúde da população idosa do município de Florianópolis-SC: estudo de base populacional" funded by Conselho Nacional de Desenvolvimento Cientifico e Tecnológico (CNPq).

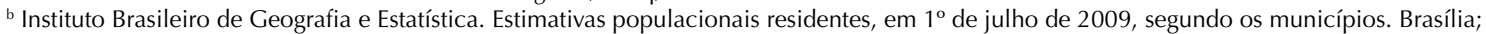
2009 [cited 2010 Aug 8]. Available from: http://www.ibge.gov.br/home/estatistica/populacao/estimativa2009/POP2009_DOU.pdf

c Organização das Nações Unidas. Programa das Nações Unidas para o Desenvolvimento. Atlas do Desenvolvimento Humano no Brasil, 2003. Brasília; 2003 [cited 2010 Aug 8]. Available from: http://www.pnud.org.br/atlas/
} 
green areas, parks, squares; safety in traffic and safety in the neighborhood. The opportunities for the practice of physical activities, like the presence of bike lanes, trails, walking paths, sports courts, and the occurrence of sports events and guided walks in the neighborhood, as well as the social support for the practice of physical activities and weather aspects were also obtained. The elderly were instructed to consider "close to their homes" the places at which they were able to arrive in up to 15 minutes on foot.

The control variables that were included were: sex; age group; self-reported skin color, excluding yellow and Indian because of the low number of occurrences ( $n=12,0.73 \% ; n=16,0.97 \%)$; marital status; level of schooling; per capita family income $\left(1^{\text {st }}\right.$ quartile: $\leq \mathrm{R} \$$ $327.50 ; 2^{\text {nd }}$ quartile: between $\mathrm{R} \$ 327.50$ and $\mathrm{R} \$ 700.00$; $3^{\text {rd }}$ quartile: between $\mathrm{R} \$ 700.00$ and $\mathrm{R} \$ 1,500.00$; and $4^{\text {th }}$ quartile: $\left.>\mathrm{R} \$ 1,500.00\right)$; cognitive status investigated by the Mini-Mental State Examination (MMSE), dichotomized in absence or probable cognitive deficit, using cut-off points that take the level of schooling into account. ${ }^{10}$ Functional capacity was determined by the scale of basic and instrumental activities of daily living (ADL) with 15 items, and was categorized into: absence of dependence, mild dependence (incapacity/ difficulty in performing 1-3 activities) and moderate/ severe dependence (incapacity/difficulty in four or more activities). ${ }^{19}$

Descriptive analyses were conducted (calculation of means, medians and standard-deviation [SD]) for numeric variables. Calculation of proportions and $95 \%$ confidence intervals $(95 \% \mathrm{CI})$ were performed for categorical variables.

To verify the association between the outcome and the independent variables of environment perception, Poisson regression was used to estimate prevalence ratios (PR) in the bivariate and multiple analyses, and $95 \%$ confidence interval $(95 \% \mathrm{CI}) .{ }^{4}$ Based on the results of the bivariate regression, all the variables that presented $\mathrm{p}<0.20$ were included in the multiple analysis, and those with $\mathrm{p}<0.05$ and/or that adjusted the model remained in the final model. The Poisson regression model was built with the variables being included in the model one by one, organized from the lowest to the highest $\mathrm{p}$ value.

The effect of each variable of environment perception on leisure-time physical activity was adjusted by demographic variables (sex and age group), socioeconomic variables (level of schooling and per capita income) and health status (functional capacity).

All the analyses were conducted in the Stata 9.0 statistical package, using the svy command, which considers the effect of cluster sampling design.
The project was approved by the Ethics Research Committee of Universidade Federal de Santa Catarina under the protocol no. 352/2008 on December 23, 2008. The subjects were informed of the study's objectives and were asked to sign a consent document.

\section{RESULTS}

In the drawn households, 1,911 eligible elderly individuals were found, of whom 1,705 were interviewed, resulting in a response rate of $89.2 \%$ (206 losses and/ or refusals). There were 49 interviews answered by caregivers (for elderly people who were unable to answer due to severe cognitive impairment) and it was decided to exclude them from the analysis, as the study aimed to analyze individual perception in relation to environment factors. The reproducibility of some questions used in the study presented kappa values between 0.3 and 0.9 .

The sample included more women than men (63.9\%). More than $86 \%$ of the elderly reported white skin color and $58.8 \%$ stated they were married or living with partners. As for the other demographic characteristics, more than half of the elderly were aged between 60 and 69 years, with variation between 60 and 102 years (mean of $70.4 ; \mathrm{SD}=7.8$ and median of 69 years), approximately $40 \%$ stated having low level of schooling ( $\leq 4$ years of schooling), with a mean of 7.6 years of schooling (SD $=5.8$ ). The mean per capita income was $\mathrm{R} \$ 1,348.97$ $(\mathrm{SD}=\mathrm{R} \$ 2,596.28$; median of $\mathrm{R} \$ 700.00)$. In relation to health conditions, the proportion of elderly people with absence of cognitive deficit was of $53.2 \%$, while $72.3 \%$ of the sample's subjects reported some dependence to perform activities of daily living (Table 1).

The prevalence of elderly people who are physically active in leisure time $(\geq 150$ minutes of leisure-time physical activity per week) was $29.7 \%$ (95\% CI $26.0 ; 33.3)$, being higher in men $(35.6 \%$ [95\% CI $29.7 ; 41.6])$ compared to women $(26.3 \%$ [95\% CI 23.1;29.4] (Figure). The elderly individuals' mean of minutes/week of leisure-time physical activity was 131.8 minutes $(\mathrm{SD}=216), 161.5$ minutes $(\mathrm{SD}=240.3)$ for men and 115.0 minutes $(\mathrm{SD}=199.2)$ for women.

Concerning environment perception, the existence of public lighting at night (90.4\%), the sensation of safety during the day $(77.5 \%)$, the existence of sidewalks $(77.3 \%)$ and of green areas $(67 \%)$ and the presence of pedestrian tracks $(62.4 \%)$ were the perceived environment factors most reported by the elderly. Approximately $70 \%$ considered the quality of the sidewalks as regular or poor (Table 2).

Table 2 also shows that leisure-time physical activity was more prevalent among the elderly who perceived

\footnotetext{
d Instituto Brasileiro de Geografia e Estatística. Perfil dos idosos responsáveis pelos domicílios no Brasil 2000. Rio de Janeiro; 2002.
} 
Table 1. Description of the sample of elderly individuals. Florianópolis, Southern Brazil, 2009-2010.

\begin{tabular}{|c|c|c|}
\hline Variable & $\mathrm{n}$ & $\%$ \\
\hline \multicolumn{3}{|l|}{ Sex } \\
\hline Male & 598 & 36.1 \\
\hline Female & 1,058 & 63.9 \\
\hline \multicolumn{3}{|l|}{ Age group (years) } \\
\hline 60 to 69 & 846 & 51.1 \\
\hline 70 to 79 & 596 & 36.0 \\
\hline 80 or more & 214 & 12.9 \\
\hline \multicolumn{3}{|l|}{ Skin color } \\
\hline White & 1,410 & 86.8 \\
\hline Mixed ethnicity (black and white) & 131 & 8.0 \\
\hline Black & 84 & 5.2 \\
\hline \multicolumn{3}{|l|}{ Marital status } \\
\hline Married/with partner & 974 & 58.8 \\
\hline Single/Divorced/Separated/ & 225 & 13.6 \\
\hline Widowed & 457 & 27.6 \\
\hline \multicolumn{3}{|l|}{ Level of schooling (years) } \\
\hline$\leq 4$ & 716 & 43.5 \\
\hline 5 to 8 & 315 & 19.1 \\
\hline 9 to 11 & 231 & 14.0 \\
\hline$\geq 12$ & 386 & 23.4 \\
\hline \multicolumn{3}{|l|}{ Per capita income in reais (quartile) } \\
\hline $1^{\text {st }}$ quartile (lowest) & 414 & 25.0 \\
\hline $2^{\text {nd }}$ quartile & 418 & 25.2 \\
\hline $3^{\text {rd }}$ quartile & 414 & 25.0 \\
\hline $4^{\text {th }}$ quartile (highest) & 410 & 24.8 \\
\hline \multicolumn{3}{|l|}{ Cognitive status } \\
\hline Without cognitive deficit & 876 & 53.2 \\
\hline With cognitive deficit & 771 & 46.8 \\
\hline \multicolumn{3}{|l|}{ Functional capacity } \\
\hline Absence of dependence & 458 & 27.7 \\
\hline Mild dependence & 707 & 42.7 \\
\hline Moderate/severe dependence & 491 & 29.6 \\
\hline
\end{tabular}

the existence of sidewalks (32.1\%), of pedestrian tracks $(32 \%)$, bike lanes, paths and trails $(38.7 \%)$ and the absence of steep areas (32.0\%) in the neighborhood; it was also more expressive among those who reported being invited by friends or relatives to practice physical activities (34.9\% and 35.3\%, respectively) and among those who perceived the weather as a barrier to the practice of physical activity $(33.3 \%)$.

Table 3 presents the crude and adjusted values of the PR of the outcome. In the crude analysis, significantly higher prevalence ratios were observed for elderly individuals who reported the existence of sidewalks $(\mathrm{PR}=1.48$ [95\%CI: 1.20; 1.84]), pedestrian tracks (PR
$=1.23[95 \%$ CI $1.00 ; 1.50])$, sensation of safety during the day $(\mathrm{PR}=1.24[95 \% \mathrm{CI} 1.04 ; 1.49])$, invitation from friends and neighbors $(\mathrm{PR}=1.24$ [95\%CI 1.07; $1.44]$ ), or from relatives $(\mathrm{PR}=1.27$ [95\% CI 1.04; 1.56]), to practice physical activities, existence of bike lanes, pedestrian paths or trails $(\mathrm{PR}=1.44[95 \% \mathrm{CI}$ $1.19 ; 1.73])$, and influence of the weather $(\mathrm{PR}=1.23$ $[95 \%$ CI $1.01 ; 1.51])$.

After the adjusted analysis, the following remained positively associated with the outcome: being invited by friends or neighbors to practice physical activities $(\mathrm{PR}=1.26[95 \% \mathrm{CI} 1.03 ; 1.43])$, the existence of bike lanes, pedestrian paths or trails in the neighborhood $(\mathrm{PR}=1.25[95 \% \mathrm{CI} 1.03 ; 1.43])$, and the influence of the weather $(\mathrm{PR}=1.26[95 \% \mathrm{CI} 1.05 ; 1.52])$ (Table 3$)$.

\section{DISCUSSION}

The main findings of the present study show important associations between factors of the perceived environment and leisure-time physical activity, independently of the effects of sociodemographic and health variables. The presence of infrastructure in the neighborhood and of social support increased the prevalence of the practice of leisure-time physical activity. Specifically, the existence of bike lanes, pedestrian paths or trails next to the households and being invited by friends or neighbors to practice physical activities were positively associated with higher level of physical activity in this domain. In the same way, although the weather was referred as a barrier to the practice of physical activities, the group who reported this situation was more active.

The proportion of elderly individuals who were physically active in leisure time was $29.7 \%$, slightly higher than the one observed in a previous study $(25.7 \%)$ carried out in the same city, with the same instrument and cut-off point. ${ }^{6}$

In a study ${ }^{1}$ conducted in the Northeast of Brazil, using the short version of the IPAQ, the authors found similar proportions of active elderly people. In the international context, the prevalence of leisure-time physical activity was also similar, $26.9 \%$ in the USA and $30.2 \%$ in Canada. ${ }^{2,13}$ However, the utilization of different instruments or criteria to classify the levels of physical activity hinders the comparison between the results of the studies.

An interesting finding was the association between existence of sidewalks and practice of leisure-time physical activity, an information that corroborates the results of the existing literature; ${ }^{11,23}$ however, this variable lost association in the adjusted analysis. It is possible that the regular or poor quality of the sidewalks in the neighborhoods, reported by approximately $70 \%$ of the elderly, has influenced this result. 
The main physical activity reported by this population was walking ${ }^{13,21}$ and the places that were frequently chosen for this activity are streets and sidewalks in the surroundings and other public spaces. These findings illustrate the importance of the presence of good quality

Table 2. Distribution of variables of environment perception and leisure-time physical activity in elderly individuals. Florianópolis, Southern Brazil, 2009-2010.

\begin{tabular}{lcccc}
\hline Variable & $\mathrm{n}$ & $\%$ & $\begin{array}{c}\text { Prevalence } \\
\text { LTPA }\end{array}$ & $95 \% \mathrm{Cl}$ \\
\hline $\begin{array}{l}\text { Existence of } \\
\text { sidewalks }\end{array}$ & 1,651 & & & \\
$\quad$ No & & 22.7 & 21.6 & $16.8 ; 26.4$ \\
$\quad$ Yes & & 77.3 & 32.1 & $28.2 ; 35.9$ \\
$\begin{array}{l}\text { Existence of green } \\
\text { areas }\end{array}$ & 1,653 & & & \\
$\quad$ No & & 33.0 & 29.0 & $23.5 ; 34.5$ \\
$\quad$ Yes & 67.0 & 30.0 & $26.0 ; 33.9$ \\
$\begin{array}{l}\text { Existence of flat } \\
\text { streets }\end{array}$ & 1,655 & & & \\
$\quad$ No & & 51.7 & 28.8 & $24.7 ; 32.8$ \\
$\quad$ Yes & & 48.3 & 30.6 & $25.3 ; 35.9$ \\
$\begin{array}{l}\text { Existence of hills that } \\
\text { limit the pathway }\end{array}$ & 1,654 & & & \\
$\quad$ No & & 56.5 & 32.0 & $27.0 ; 37.0$ \\
$\quad$ Yes & & 43.5 & 26.7 & $22.7 ; 30.7$
\end{tabular}

Existence of accumulation of garbage on the 1,653 streets

$$
\begin{aligned}
& \text { No } \\
& \text { Yes }
\end{aligned}
$$

Existence of open sewer

$$
\begin{aligned}
& \text { No } \\
& \text { Yes }
\end{aligned}
$$

Difficulty in walking or riding a bicycle due to the traffic

$\begin{array}{llll}\text { No } & 63.0 & 30.2 & 25.8 ; 34.6 \\ \text { Yes } & 37.0 & 29.7 & 24.9 ; 34.5\end{array}$

Existence of pedestrian tracks

1,647

$$
\begin{aligned}
& \text { No } \\
& \text { Yes }
\end{aligned}
$$

Existence of pollution smoke

1,652

$\begin{array}{lll}88.3 & 30.4 & 26.6 ; 34.2 \\ 11.7 & 24.4 & 17.1 ; 31.6\end{array}$

1,636

$\begin{array}{lll}84.1 & 30.3 & 26.4 ; 34.2\end{array}$

$\begin{array}{lll}84.1 & 30.3 & 26.4,34.2 \\ 15.9 & 26.6 & 20.5 ; 32.7\end{array}$

1,653

No
Yes

Existence of public lighting in the streets 1,649
at night

\begin{tabular}{cccc} 
No & 9.6 & 28.9 & $20.9 ; 37.0$ \\
Yes & 90.4 & 29.8 & $26.0 ; 33.6$ \\
\hline
\end{tabular}

To be continued
Table 2 continuation

\begin{tabular}{lcccc}
\hline Variable & $\mathrm{n}$ & $\%$ & $\begin{array}{c}\text { Prevalence } \\
\text { LTPA }\end{array}$ & $95 \% \mathrm{Cl}$ \\
\hline $\begin{array}{l}\text { Sensation of safety } \\
\text { during the day }\end{array}$ & 1,643 & & & \\
$\quad$ & & & \\
$\quad$ No & 22.5 & 25.1 & $20.8 ; 29.5$ \\
$\quad$ Yes & 77.5 & 31.3 & $27.2 ; 35.4$
\end{tabular}

Sensation of safety during the night

1,630

$\begin{array}{llll}\text { No } & 66.9 & 30.3 & 26.5 ; 34.0 \\ \text { Yes } & 33.1 & 29.3 & 23.4 ; 35.2\end{array}$

Invitation from friends or neighbors to practice physical activities

$\begin{array}{llll}\text { No } & 74.5 & 28.2 & 24.6 ; 31.7 \\ \text { Yes } & 25.5 & 34.9 & 29.2 ; 40.6\end{array}$

Invitation from

relatives to practice $\quad 1,639$

physical activities

$\begin{array}{llll}\text { No } & 71.0 & 27.7 & 24.4 ; 30.9 \\ \text { Yes } & 29.4 & 35.3 & 28.2 ; 42.4\end{array}$

Existence of bike

lanes, pedestrian

paths and trails of

1,637 easy access

$\begin{array}{llll}\text { No } & 73.8 & 26.9 & 23.8 ; 30.0 \\ \text { Yes } & 26.2 & 38.7 & 31.5 ; 5.9\end{array}$

Existence of parks, squares, walking paths, sports courts 1,641 of easy access

$\begin{array}{llll}\text { No } & 63.7 & 29.2 & 24.3 ; 34.0 \\ \text { Yes } & 36.3 & 31.3 & 26.3 ; 36.2\end{array}$

Occurrence of sports events in the 1,637 neighborhood

$\begin{array}{llll}\text { No } & 79.4 & 28.9 & 24.7 ; 33.1 \\ \text { Yes } & 20.6 & 33.5 & 27.4 ; 39.7\end{array}$

The weather (cold, rain, heat) limits the practice of physical 1,607 activities $^{\mathrm{a}}$

\begin{tabular}{llll} 
No & 49.2 & 27.1 & $22.5 ; 31.7$ \\
Yes & 50.8 & 33.3 & $28.4 ; 38.2$ \\
\hline
\end{tabular}

LTPA: leisure-time physical activity

${ }^{\mathbf{a}}$ Variable with the highest number of ignored observations $=49$.

sidewalks and streets as an environment that facilitates physical activity, as well as the relevance of researching and intervening in the characteristics of urban spaces that favor leisure activities. ${ }^{9,14,20}$

This research showed that proximity to leisure structures, like bike lanes, pedestrian paths or trails was significantly associated with higher level of leisure-time physical activity, in agreement with the literature. ${ }^{8,14,15}$ These urban spaces that offer easy-to-access leisure 
structures for the practice of physical activity can also play an important role in the active behavior patterns of the elderly population.

Previous studie ${ }^{14,15}$ have identified positive associations between accessibility to leisure structures, like parks, green areas, trails and bike lanes, as well as the quality of these environments in the neighborhood, with active behavior. On the other hand, Booth et $\mathrm{a}^{8}$ (2000) have confirmed that the structural limitations in the environment represent obstacles to the practice of physical activity, verifying that older adults who do not live close to leisure structures and spaces tend to be less physically active.

The positive role played by social support in the elderly individuals' practice of physical activity has been observed in other studies. ${ }^{3,17,21}$ According to these researchers, physical activity becomes more pleasant when one has company, and social support acts intrinsically by means of the incentive and of partnerships between friends and neighbors, and extrinsically, motivating other people to exercise in the neighborhood's environment.

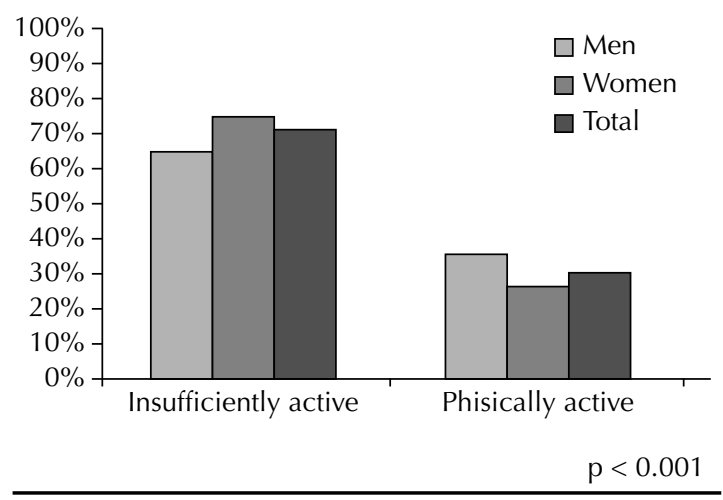

Figure. Prevalence of leisure-time physical activity in elderly individuals. Florianópolis, Southern Brazil, 2009-2010.

Elderly people in the present study who reported that the weather is a barrier to the practice of physical activities presented higher prevalence of the outcome. It is possible that active elderly individuals expose themselves more frequently to adverse weather conditions and thus reported this fact as a barrier, but not an impediment to the practice of physical

Tabela 3. Crude and adjusted prevalence ratios of the association between leisure-time physical activity and environment perception variables among elderly individuals. Florianópolis, Southern Brazil, 2009-2010.

\begin{tabular}{|c|c|c|c|c|}
\hline \multirow{2}{*}{ Variable } & \multicolumn{2}{|c|}{ Crude analysis } & \multicolumn{2}{|c|}{ Adjusted analysis ${ }^{\mathbf{a}}$} \\
\hline & PR $(95 \% \mathrm{Cl})$ & $\mathrm{p}$ & PR $(95 \% \mathrm{Cl})$ & $\mathrm{p}$ \\
\hline Existence of sidewalks & & $<0.001^{\mathbf{b}}$ & $1.22(0.97 ; 1.53)$ & 0.09 \\
\hline No & 1 & & & \\
\hline Yes & $1.48(1.20 ; 1.84)$ & & & \\
\hline Existence of green areas & & 0.74 & & \\
\hline No & 1 & & & \\
\hline Yes & $1.03(0.85 ; 1.26)$ & & & \\
\hline Existence of flat streets & & 0.54 & & \\
\hline No & 1 & & & \\
\hline Yes & $1.06(0.87 ; 1.30)$ & & 1 & \\
\hline Existence of hills that limit the pathway & & $0.07^{\mathbf{b}}$ & $0.89(0.74 ; 1.08)$ & 0.22 \\
\hline No & 1 & & & \\
\hline Yes & $0.84(0.69 ; 1.01)$ & & & \\
\hline Existence of accumulation of garbage on the streets & & 0.29 & & \\
\hline No & 1 & & & \\
\hline Yes & $0.88(0.69 ; 1.12)$ & & 1 & \\
\hline Existence of open sewer & & $0.15^{\mathbf{b}}$ & $0.81(0.61 ; 1.07)$ & 0.13 \\
\hline No & 1 & & & \\
\hline Yes & $0.80(0.59 ; 1.08)$ & & & \\
\hline Difficulty in walking or riding a bicycle due to the traffic & & 0.86 & & \\
\hline No & 1 & & & \\
\hline Yes & $0.98(0.82 ; 1.18)$ & & 1 & \\
\hline Existence of pedestrian tracks & & $0.05^{\mathbf{b}}$ & $0.99(0.80 ; 1.23)$ & 0.96 \\
\hline No & 1 & & 1 & \\
\hline Yes & $1.23(1.00 ; 1.50)$ & & $0,99(0,80 ; 1,23)$ & \\
\hline
\end{tabular}

To be continued 
Table 3 continuation

\begin{tabular}{|c|c|c|c|c|}
\hline \multirow{2}{*}{ Variable } & \multicolumn{2}{|c|}{ Crude analysis } & \multicolumn{2}{|c|}{ Adjusted analysis $^{\mathbf{a}}$} \\
\hline & PR $(95 \% \mathrm{Cl})$ & $\mathrm{p}$ & PR $(95 \% \mathrm{Cl})$ & $\mathrm{p}$ \\
\hline Existence of pollution smoke & & 0.28 & & \\
\hline Não & 1 & & & \\
\hline Sim & $1.15(0.89 ; 1.47)$ & & & \\
\hline Existence of public lighting in the streets at night & & 0.834 & & \\
\hline No & 1 & & & \\
\hline Yes & $1.03(0.78 ; 1.36)$ & & & \\
\hline Sensation of safety during the day & & $0.02^{\mathbf{b}}$ & & 0.23 \\
\hline No & 1 & & 1 & \\
\hline Yes & $1.24(1.04 ; 1.49)$ & & $1.11(0.94 ; 1.31)$ & \\
\hline Sensation of safety during the night & & 0.75 & & \\
\hline No & 1 & & & \\
\hline Yes & $0.97(0.80 ; 1.18)$ & & & \\
\hline Invitation from friends or neighbors to practice physical activities & & $0.006^{\mathbf{b}}$ & & $0.008^{\mathbf{c}}$ \\
\hline No & 1 & & 1 & \\
\hline Yes & $1.24(1.07 ; 1.44)$ & & $1.26(1.03 ; 1.43)$ & \\
\hline Invitation from relatives to practice physical activities & & $0.02^{\mathbf{b}}$ & & 0.15 \\
\hline No & 1 & & 1 & \\
\hline Yes & $1.27(1.04 ; 1.56)$ & & $1.15(0.95 ; 1.34)$ & \\
\hline Existence of bike lanes, pedestrian paths and trails of easy access & & $<0.001^{\mathbf{b}}$ & & $0.02^{c}$ \\
\hline No & 1 & & 1 & \\
\hline Yes & $1.44(1.19 ; 1.73)$ & & $1.25(1.03 ; 1.43)$ & \\
\hline $\begin{array}{l}\text { Existence of parks, squares, walking paths, sports courts of easy } \\
\text { access }\end{array}$ & & 0.54 & & \\
\hline No & 1 & & & \\
\hline Yes & $1.73(0.86 ; 1.34)$ & & & \\
\hline Occurrence of sports events in the neighborhood & & $0.19^{\mathbf{b}}$ & & 0.86 \\
\hline No & 1 & & 1 & \\
\hline Yes & $1.16(0.93 ; 1.45)$ & & $1.02(0.84 ; 1.23)$ & \\
\hline $\begin{array}{l}\text { The weather (cold, rain, heat) limits the practice of physical } \\
\text { activities }\end{array}$ & & $0.04^{\mathbf{b}}$ & & $0.02^{\mathrm{c}}$ \\
\hline No & 1 & & 1 & \\
\hline Yes & $1.23(1.01 ; 1.51)$ & & $1.26(1.05 .1 .52)$ & \\
\hline
\end{tabular}

a Adjusted by sex, age group, level of schooling, income and functional capacity.

${ }^{b}$ Variables included in the multivariable analysis.

c Variables that remained in the final model.

activity. Furthermore, Florianópolis has well-defined seasons, with a pleasant average annual temperature, which may not represent an obstacle to the practice of physical activity.

Conversely, a recent systematic review of the theme ${ }^{24}$ has shown that the weather has a significant impact on this outcome and that bad or extreme weather is recognized as a barrier to the practice of physical activity.

Some methodological limitations of the present study should be considered, mainly the cross-sectional design, which does not allow to define causality relations between leisure-time physical activity and the environment factors. Objective information on the environment was not collected, only information about individual perception. However, this form of questioning has been widely used in studies of this nature with the aim of observing information reported by the elderly based on the perceptions of the environment in which they are inserted. Moreover, the physical activity assessment instrument that was employed (IPAQ) is recommended to individuals aged 18-64 years, although it has been validated and frequently applied to populations of Brazilian elderly people. ${ }^{1,5,6,21}$

Among the positive points, it is possible to mention that the study was carried out in a large and representative 
sample of older adults of a Brazilian capital city. Also, it reproduced the population structure of the municipality ${ }^{\mathrm{d}}$ according to gender and age group and ensured the extrapolation of the results to the population as a whole. Another positive point was the high return rate in all income strata, which contributed to the study's internal validity, reducing the odds of occurrence of systematic errors.

Ascertaining that adequate environments to the practice of leisure-time physical activity in the neighborhoods contribute to an active behavior represents an important finding that may subsidize urban planning and public health policies. These policies include the design of interventions in the construction and maintenance of public leisure spaces, as well as social support, by means of group activities.

\section{REFERENCES}

1. Alves JGB, Siqueira FV, Figueiroa JN, Facchini LA, Silveira DS, Piccini RX, et al. Prevalência de adultos e idosos insuficientemente ativos moradores em áreas de unidades básicas de saúde com e sem Programa Saúde da Família em Pernambuco, Brasil. Cad Saude Publica. 2010;26(3):543-56. DOI:10.1590/S0102311X2010000300012

2. Ashe MC, Miller WC, Eng J, Noreau L. Older adults, chronic disease and leisure-time physical activity. Gerontology. 2009;55(1):64-72. DOI:10.1159/000141518

3. Ball K, Bauman A, Leslie E, Owen N. Perceived environmental aesthetics and convenience and company are associated with walking for exercise among Australian adults. Prev Med. 2001;33(5):43440. DOI:10.1006/pmed.2001.0912

4. Barros AJ, Hirakata VN. Alternatives for logistic regression in cross-sectional studies: an empirical comparison of models that directly estimate the prevalence ratio. BMC Med Res Methodol. 2003;3:21. DOI:10.1186/1471-2288-3-21

5. Benedetti TRB, Mazo GZ, Barros MVG. Aplicação do Questionário Internacional de Atividades Físicas para avaliação do nível de atividades físicas de mulheres idosas: validade concorrente e reprodutibilidade testereteste. Rev Bras Cienc Mov. 2004;12(1):25-34.

6. Benedetti TRB, Borges LJ, Petroski EL, Gonçalves LHT. Atividade física e estado de saúde mental de idosos. Rev Saude Publica. 2008;42(2):302-7. DOI:10.1590/ S0034-89102008005000007

7. Berke EM, Koepsell TD, Moudon AV, Hoskins RE, Larson EB. Association of the built environment with physical activity and obesity in older persons. Am J Public Health. 2007;97(3):486-92. DOI:10.2105/ AJPH.2006.085837

8. Booth ML, Owen N, Bauman A, Clavisi O, Leslie E. Social-Cognitive and Perceived Environment Influences Associated with Physical Activity in Older Australians.
In view of the relevance of this theme, it is suggested that longitudinal studies are conducted aiming at a better understanding of the environmental factors, by means of objective information and of elderly people's individual perception, as well as their relation to the practice of physical activity during leisure time and in other contexts.

\section{ACKNOWLEDGEMENTS}

To Prof. Dr. Nilza Nunes de Souza, with the Epidemiology Department of the School of Public Health of Universidade de São Paulo, for her contributions about sampling procedures.

To the technicians of Instituto Brasileiro de Geografia e Estatística and to the Florianópolis Municipal Health Department, for the logistic support.
Prev Med. 2000;31(1):15-22. DOI:10.1006/ pmed.2000.0661

9. Brownson RC, Baker EA, Housemann RA, Brennan LK, Bacak SJ. Environmental and policy determinants of physical activity in the United States. Am J Public Health. 2001; 91(12):1995-2003. DOI:10.2105/ AJPH.91.12.1995

10. Brucki SM, Nitrini R, Caramelli P, Bertolucci PHF, Okamoto IH. Sugestões para o uso do mini-exame do estado mental no Brasil. Arq Neuropsiquiatr. 2003;61(3B):777-81. DOI: 10.1590/S0004282X2003000500014

11. Gallagher NA, Gretebeck KA, Robinson JC, Torres ER, Murphy SL, Martyn KK. Neighborhood factors relevant for walking in older, urban, African American adults. J Aging Phys Act. 2010;18(1):99-115.

12. Gregg EW, Cauley JA, Stone K, Thompson TJ, Bauer DC, Cummings SR, et al. Relationship of changes in physical activity and mortality among older women. JAMA. 2003;289(18):2379-86.DOI: 10.1001/ jama.289.18.2379

13. Hughes JP, McDowell MA, Brody DJ. Leisure-time physical activity among US adults 60 or more years of age: results from NHANES 1999-2004. J Phys Act Health. 2008;5(3):347-58.

14. Huston SL, Evenson KR, Bors P, Gizlice Z. Neighborhood environment, access to places for activity, and leisure-time physical activity in a diverse North Carolina population. Am J Health Promot. 2003;18(1):58-69. DOI:10.4278/0890-1171-18.1.58

15. Li F, Harmer PA, Cardinal BJ, Bosworth M, Acock A, Johnson-Shelton $\mathrm{D}$, et al. Built environment, adiposity, and physical activity in adults aged 50-75. Am J Prev Med. 2008; 35(1):38-46.

16. Malavasi LM, Duarte MFS, Both J, Reis RS. Escala de Mobilidade Ativa no Ambiente Comunitário News Brasil: tradução e reprodutibilidade. Rev Bras Cineantropom Desempenho Hum. 2007;9(4):339-50. 
17. Mathews AE, Laditka SB, Laditka JN, Wilcox S, Corwin SJ, Liu R, et al. Older adults' perceived physical activity enablers and barriers: a multicultural perspective. I Aging Phys Act. 2010;18(2):119-40.

18. Nelson ME, Rejeski JW, Blair SN, Duncan PW, Judge JO, King AC, et al. Physical activity and public health in older adults: recommendation from the American College of Sports Medicine and the American Heart Association. Med Sci Sports Exerc. 2007;39(8):143545. DOI:10.1249/mss.0b013e3180616aa2

19. Rosa TEC, Benício MHD, Latorre MRDO, Ramos LR. Fatores determinantes da capacidade funcional entre idosos. Rev Saude Publica. 2003;37(1):40-8. DOI:10.1590/S0034-89102003000100008

20. Sallis JF, Bowles HR, Bauman A, Ainsworth BE, Bull FC, Craig CL, et al. Neighborhood Environments and Physical Activity Among Adults in 11 Countries. Am J Prev Med. 2009;36(6):484-90. DOI:10.1016/j. amepre.2009.01.031
21. Salvador PE, Florindo AA, Reis RS, Costa, EF. Percepção do ambiente e prática de atividade física no lazer entre idosos. Rev Saude Publica. 2009;43(6):97280. DOI:10.1590/S0034-89102009005000082

22. Sawatzky R, Liu-Ambrose T, Miller WC, Marra CA. Physical activity as a mediator of the impact of chronic conditions on quality of life in older adults. Health Qual Life Outcomes. 2007;5:68.

23. Strath S, Isaacs R, Greenwald MJ. Operationalizing environmental indicators for physical activity in older adults. J Aging Phys Act. 2007;15(4):412-24.

24. Tucker P, Gilliland J. The effect of season and weather on physical activity: a systematic review. Public Health. 2007;121(12):909-22. DOI:10.1016/j. puhe.2007.04.009

25. Zaitune MPA, Barros MBA, César CLG, Carandina L, Goldbaum M. Fatores associados ao sedentarismo no lazer em idosos, Campinas, São Paulo, Brasil. Cad Saude Publica. 2007;23(6):1329-38. DOI:10.1590/ S0102-311X2007000600008

Paper based on the Master's dissertation authored by Giehl MWC and submitted to Universidade Federal de Santa Catarina in 2010.

Giehl MWC was supported by Coordenação de Aperfeiçoamento de Pessoal de Nível Superior (CAPES; Master scholarship). Research funded by Conselho Nacional de Desenvolvimento Científico e Tecnológico (CNPq - Process no. 569834/2008-2). The authors declare no conflicts of interests. 